\title{
A Body of Authority: Reorienting Gender and Power in Julian of Norwich's Revelations
}

\author{
Phillip Goodwin (D)
}

check for updates

Citation: Goodwin, Phillip. 2021. A Body of Authority: Reorienting Gender and Power in Julian of Norwich's Revelations. Humanities 10: 30. https://doi.org/10.3390/ h10010030

Received: 15 January 2021

Accepted: 10 February 2021

Published: 12 February 2021

Publisher's Note: MDPI stays neutral with regard to jurisdictional claims in published maps and institutional affiliations.

Copyright: (C) 2021 by the author. Licensee MDPI, Basel, Switzerland. This article is an open access article distributed under the terms and conditions of the Creative Commons Attribution (CC BY) license (https:// creativecommons.org/licenses/by/ $4.0 /)$.
Department of English, University of Northern Colorado, Greeley, CO 80639, USA; phillip.goodwin@unco.edu

\begin{abstract}
The 14th century mystic Julian of Norwich's theology, dissolving gender binaries and incorporating medieval constructs of the female into the Trinity, captivates scholars across rhetorical, literary, and religious studies. A "pioneering feminist", as Cheryll Glenn dubs her, scholarship attempts to account for the ways in which Julian's theology circumvented the religious authority of male clerics. Some speculate that Julian's authority arises from a sophisticated construction of audience (Wright). Others situate Julian in established traditions and structures of the Church, suggesting that she revised a mode of Augustinian mysticism (Chandler), or positing that her intelligence and Biblical knowledge indicate that she received religious training (Colledge and Walsh). Drawing from theories on space and gender performativity, this essay argues that Julian's gendered body is the generative site of her authority. Bodies are articulated by spatial logics of power (Shome). Material environments discipline bodies and, in a kind of feedback loop, gendered performance (re)produces power in time and space. Spaces, though, are always becoming and never fixed (Chavez). An examination of how Julian reorients hierarchies and relations among power, space, and her body provides a hermeneutic for recognizing how gender is structured by our own material cultures and provides possibilities for developing practices that revise relations and create new agencies.
\end{abstract}

Keywords: Julian of Norwich; materiality; spatial rhetoric; gender

The 14th century mystic Julian of Norwich's theological writings captivate scholars across rhetorical, literary, and religious studies. Intriguing to scholars is not just that her theology challenges the authority of male clerics and circumvents hierarchies and gendered binaries established in the male-centric theology of the Church. Her works are the earliest extant texts in English known to be written by a woman, and because of the sophistication of her thought as well as her prose, her writing is often compared with her contemporary Geoffrey Chaucer. Julian's Revelations of Divine Love comprises two texts: A Vision Showed to a Devout Woman and A Revelation of Love. Often referred to as the Short Text and the Long Text, Revelation (the Long Text) significantly revises and expands the original Vision (the Short Text) and was (re)written over a roughly twenty-year period while she lived as an anchoress at the Church of St. Julian, after which she is likely named. Both texts narrate and ruminate on the same visionary experience dating to 1373, when Julian was thirty years-old and suffered a severe illness that brought her near death. While on her deathbed and fixated on a cross before her, Julian communed with God, who provided her with sixteen "showings" concentrating on Christ's Passion and the holiness of the Mother Mary. Through these showings, God reveals the nature of the Trinity and the unity of all creation. The Godhead encompasses both sexes, God-as-Father as well as Mother, while God's humanity is fused to all humanity and exists within His eternal "substance." Julian, contemplating God's universal love for all humanity, writes a place for women in divinity. Moreover, her revelation of God's co-existence with and within humanity bridges the material and spiritual worlds and provides a hermeneutic through which all lay-Christians, including women, can directly access God and the divine. 
Within a wide-ranging literature on Julian, much scholarship attempts to account for how a woman in late medieval England could produce, as Kim A. Phillips (2008) describes it, such "complex and highly original theological tracts" (p. 29). Though almost nothing is known of Julian's life beyond what little biographical information is included in her texts and a handful of local records, one strand of this scholarship relies on speculation that Julian was a convent-educated Benedictine nun prior to her internment as an anchoress. This biography was popularized in the 1970s by her editors Edmund Colledge and James Walsh, both Jesuit Priests. Citing evidence gleaned from her writing, they imagine that her work could only come from "profound knowledge ... and familiar[ity] with a wide range of the classical spiritual writings that were the foundations of the monastic contemplative tradition of the Western Church" (Colledge and Walsh 1978, p. 20). They contend that this level of knowledge could only come from "ha[ving] entered a religious order when she was young [and] it must have been there that she acquired her academic training" (p. 20). Colledge and Walsh's construction of Julian as an educated nun serves as foundation for other scholarship and situates her within Church traditions. Robert E. Wright (1987), for example, speculates that her authority rises from a sophisticated construction of audience that relies on a deep understanding of an Augustinian rhetorical model for communicating the inexpressibility of the divine. Erin T. Chandler (2012) similarly argues that Julian was aware of an extant tradition of Christian mystical writing and writes within its rhetorical mode. Though Chandler affords that Julian "revised" this mode of writing, constructing Julian as a widely read and educated nun sanctions her theology and writing within structures of the Church.

A different strand of this scholarship imagines Julian as a savvy negotiator of gendered social politics. Women and femininity play a central role in Julian's theology. Rather than crafting a secure biography and using it as a hermeneutic for reading Julian's texts, this scholarship seeks to contextualize her writing within a broad range of cultural-political contexts. Along these lines, Phillips (2008) writes that femininity is experiential, and that in the classed society of late medieval England, women necessarily understood and played various feminine roles for social acceptance (pp. 21-22). She contends Julian's performance of feminine piety in her writing, and while housed within the institutional structures of an anchorhold, afforded her the time and opportunity to contemplate and engage "original theological thought" (p. 31). Felicity Riddy (1998) suggests that to write religious texts as an anchoress, Julian's authorial identity was subject to male clerical authority, sanctioning, and, perhaps, collaboration within Church hierarchy (p. 106). This scholarship recognizes that the authority to relay her theological revelations required Julian to both subvert and conform to a gendered social-political order. This position was not unique to Julian. As Nicholas Watson (1996) writes, "medieval women writers often respond to the gender stereotypes which they inherit from their culture neither by accepting nor by rejecting them, but rather by thinking through them in as active and positive way as possible" (p. 8). Put differently, this scholarship suggests Julian worked within the limited means available to women in her time to exercise religious agency.

Drawing on theories of space and gender performativity this essay seeks to supplement and to complicate these strands of scholarship by arguing that Julian's gendered body is the generative site of her authority. Her corporeal communion with God subjects Julian to a new authority that grants her new possibilities and agencies not afforded to other women situated within the material and patriarchal-cultural construct of the medieval Church and society. To examine how Julian opens rhetorical space within confluences among space, power, and her body, I begin by examining how Julian's bodily experience and theology repositions her as subject to a new mode of bodily authority and power. I then examine how Julian's embodiment of her new subjectivity allows her to reorient her relationships to her fellow Christians in ways that subvert the gendered social and institutional politics within which she was articulated as an anchoress. I conclude by suggesting how Julian's positionality within overlapping paradigms of power provides us with a hermeneutic for revising relations of power and enacting new agencies in our own time. 
There is a complex relationship between Julian's theology and the political-religious matrix of power within which she experienced her revelations and within which she writes. Raka Shome (2003) observes that bodies are articulated through spatial logics of power. Space, she writes, "penetrates" social frameworks and is "a force that helps constitute ... social relations" (p. 41). Many scholars, for example, recognize the anchorhold as a socially constructed and gendered space. (McAvoy 2008a; Cedillo 2015; Cannon 2003; Davis 2008). Liz Herbert McAvoy (2008a) writes that female anchorites tended to come from the religious laity, which required her to petition male authorities like a bishop or an abbot to prove her piety and devotion (p. 120). Moreover, as Christina Cedillo (2015) notes, religious women enclosed within the institution of the Church were encouraged to seek an androgynous being. For women, assuming androgyny is articulated through a male-construed mode of feminine piety including strict adherence to a rigorous form of ascetic, bodily chastity. As Roxanne Mountford (2001) contends, space is rhetorical. Although anchorites withdrew from society, they served an important social function as models of sanctity and religious inspiration, by providing counsel to the faithful, among other roles. The spatial rubric of the anchorhold extends beyond its physical structure. An Anchoress' body in space reiterates power and gendered hierarchies of the church through subordination to male religious authority and the performance of an extreme ideal of feminine piety. The anchorhold, then, materially and symbolically reinforces religious authority in the person of the male cleric.

Julian's corporeal communion with God wrought by her illness, however, places her body outside the jurisdiction of the Church. Her theology develops from experiential knowledge. As such, Julian's body became the threshold for accessing divine knowledge and a rhetorical site of meaning-making. This affords her new possibilities for embodying her femininity and advancing her theological revelations while situated within the context of the anchorhold. In Vision and Revelation, Julian expresses her union with God through a narrative accounting of her visionary experience. In both texts, she describes the feeling and action of dying, including her "hands f[alling, ] ... [her] head loll[ing] to one side," and the "greatest pain" that was her "shortness of breath and the ebbing of [her] life" (eds. Colledge and Walsh 1978, p. 128). It is at this point that Julian receives her first vision of Christ's crucifixion. The vision, which she understands to come directly from God, transports her back in time to the moment when the crown of thorns is thrust on Jesus head. She describes the sight of "red blood running down from under the crown, hot and flowing freely and copiously, a living stream" (eds. Colledge and Walsh 1978, p. 181). Following the practice of affective piety, Julian concentrates on the physical suffering of Jesus while meditating on the love and sorrow of Mary. Julian bears witness to Christ's crucifixion through embodying Mary and seeing through her eyes and feeling her sorrow. In the midst of her revelations and at the point of Jesus' death, however, Julian's narrative breaks from a traditional accounting of affective piety as her vantage changes to that of Christ's. Her body interchanges with Christ's as Julian's bodily illness and pain becomes his suffering. She writes: "Christ was present to me, I felt no pain except Christ's pains" (eds. Colledge and Walsh 1978, p. 209). Julian continues: "Here I saw great unity between Christ and us" (eds. Colledge and Walsh 1978, p. 209). Carmel Bendon Davis (2008) describes this moment as one of "coexistence" between Julian and the human Jesus (p. 235). "Julian's bodily suffering," Davis writes, "is elevated to a higher spiritual plane in which bodily illness and spiritual insight become paired" (p. 235). Julian's felt bodily experiences and the revelation occur simultaneously. Julian's body becomes the meeting place between the spiritual and the physical world and a site of divine knowledge.

Julian's revelations reveal the nature of God's being. A primary assertion of her theology is that God's presence in all creation unites God with all of humanity. Julian's realization of the interconnectedness of God and humanity suggests a shared spatiality in which the space between the physical and metaphysical collapses. Writing that she "saw no difference between God and our substance", Julian describes: 
Greatly ought we to rejoice that God dwells in our soul; and more greatly ought we to rejoice that our soul dwells in God. Our soul is created to be God's dwelling place, and the dwelling of our soul is God ... It is a great understanding to see and know inwardly that our soul, which is created, dwells in God in substance, of which substance, through God, we are what we are (eds. Colledge and Walsh 1978, p. 285).

Davis (2008) writes that Julian's revelations offer "remarkable changes of perspective", in which God is "both container and that which is contained" (p. 229). We reside in God and God resides in us. The singularity of all creation fuses humanity to God. Moreover, Julian's cascading revelations reveal that the one-ness of all creation is maintained through the eternal consistency of God's love. All of creation is, as she describes it in numerous places throughout her texts, "one love." Julian's revelations dissolve boundaries between ourselves and God. To find union with God, then, requires meeting Him in His love.

Julian's revelation of unity and that all of humanity and creation are "all one love" circumvents male religious authority. This opens a rhetorical space through which Julian subverts subjecting forces of dominant gender norms. Broadly, medieval law, society, and cultural practice were inexorably tied-up with the Church and informed by its theology. Across these sites, women played a subordinate role to masculine privilege and male, religious authority. Karma Chávez (2010) argues that relations of power in space and time "marks the body" (p. 5). Medieval women were inscribed with associations to Eve and temptation. That impurity and sin was a natural feature of womanhood was canonized in Church writings and circulated from the pulpit. Cheryl Glenn (1997) relates that both St. Augustine and St. Thomas Aquinas connected women's "weaker temperament," and thus a proclivity for sinning, to biological imperfections (pp. 77-78). Alcuin Blamires (2003) notes that in medieval sermons, "criticism of female instability, credulity, vanity and sexual incitement was ubiquitous" (p. 149). Marking women's bodies as inherently corrupt informed mores and oriented practices and performances of appropriate modes of femininity. Cedillo (2015) notes that medieval femininity was framed as "either wholly virtuous or wholly corrupt" (p. 78). Quoting Liz Herbert McAvoy, Cedillo continues: "Women could only achieve 'the pinnacle of sanctity' if they 'transcend[ed] the monstrous and appetitive corporeality of imperfect womanhood"' (p. 79). This led to privileging virginity and chastity wherein, ground in the writings of St. Jerome, "[v]irginity represent[ed] the closest thing on earth to prelapsarian purity" (Evans 2003, p. 25). Inherent sin sexes women's bodies and orients gendered practices. Women were encouraged to model themselves after the Virgin Mary, who was exalted for her purity and sinless life (Blamires 2003, pp. 149-51; Glenn 1997, pp. 78, 193, n. 13). Women who maintained and performed piety as a mode of femininity enjoyed greater social status over other women (Evans 2003, p. 25; Phillips 2008, pp. 23-24). Inherent sin subjects women and their bodies to mores entrenched in canonical Church writings and doctrines that are aligned with male superiority and which translate across religious, social, and cultural spaces.

Yet, the coalescence of the body with the divine consequently leads to one of the most radical aspects of Julian's theology: that "[s]in is necessary" (eds. Colledge and Walsh 1978, p. 148). While bearing witness to Christ's Passion, Julian contemplates the purpose of Christ's pain in humanity's redemption. At this moment, God reveals another vision in which she feels her longing to be united in God's grace. She writes: "The Lord brought to my mind the longing that I had for him before; and I saw that nothing hindered me but sin, and I saw that this is true of us all in general, and it seemed to me that if there had been no sin, we should have been pure and as like our Lord as he created us" (eds. Colledge and Walsh 1978, pp. 147-48). Yet, as Jesus reveals to Julian, sin brings us to a place of contrition and humbles us before God. On the nature of sin, Julian writes: "I believe that it has no kind of substance, no share in being, nor can it be recognized except by the pains which it causes. And it seems to me that this pain is something for a time, for it purges us and makes us know ourselves and ask for mercy" (eds. Colledge and Walsh 1978, pp. 148-49). Sin primes us for meeting God in love. Sin is also the object of God's 
compassion and is forgiven through his love. It is necessary because it creates the meeting place and the point of union between God and humanity. In Julian's instruction, we must seek God through contrition and prayer. "Prayer," she writes, "unites the soul to God, for although the soul may always be like God in nature and substance, it is often unlike him in condition, through human sin" (eds. Colledge and Walsh 1978, p. 158). When we remove sin through prayer and longing for God, "God and the soul are wholly at unity and God and man are wholly one" (eds. Colledge and Walsh 1978, p. 167). Without sin, we cannot be humble, and without humility, we cannot meet God in His love, grace, and mercy.

Julian expands her contemplation and revelation of the necessity of sin in the Long Text. There, she includes a visionary allegory shown by God about a lord and his servant that was not in the Short Text. In this vision the lord, sitting humbly on the ground, sends the servant, who stands above him, on an errand. In his eagerness to please his lord, the servant trips, falls, and is injured and in such pain that he cannot rise on his own. The lord exalts the servant and meets the servant's failure with love. The servant's reward is greater than if he had dutifully performed the task. Julian comes to understand that falling was the true task for the servant, so that with graciousness, the lord could turn the servant's "woe" into "high, surpassing honour and endless bliss" (eds. Colledge and Walsh 1978, p. 269). Almost immediately, Julian recognizes the vision is about Adam and all of humanity's relationship with God. With further reflection, though, she comes to understand that it is about disunity and the (re)unification of the Trinity, as well as humanity's union within the entire being of God. Julian writes: "we have in us a marvelous mixture of well-being and woe. We have in us our risen Lord Jesus Christ, and we have in us the wretchedness and the harm of Adam's falling" (eds. Colledge and Walsh 1978, p. 279). As Davis (2008) describes it, "Julian melds Christ's rising and Adam's (and humanity's) falling into the two aspects of salvation" (p. 238). Falling from grace and rising to salvation are not as separate as Church teaching imagines. Julian's revelation replaces the Church's binary opposition between sinner and piety. The union of opposites is necessary to find union with God and the whole of creation.

Moreover, though, Julian's revelations envision union with God as a dynamic process. Like the collapsing of binary positions described above, Julian's revelations again reorient the relationship between humanity and God in ways that differ from Church teaching. Julian writes:

[I]n our Lord's intention I saw and understood that we cannot in this life keep ourselves completely from sin, in the prefect purity that we shall have in heaven ... And if we through our blindness and our wretchedness at any time fall, then let us quickly rise, knowing the sweet touching of grace ... and go on our way with God in love. (eds. Colledge and Walsh 1978, p. 281)

Julian explains a reiterative process. Sinning is natural to our being. Our "mixture of wellbeing and woe" necessitates our repeated falling and our repeated rising. Watson (2003) suggests that in this understanding, sin "is a process of testing, in which the soul is made fit to be the dwelling-place of God" (p. 217). Carrying Watson's observation further, repeated falling and rising maintains a constant and active engagement with God. Our natural sinning conditions a necessary humility to be one in God's love. There is an affective element to Julian's instruction. Julian writes: "Peace and love are always in us, living and working" (eds. Colledge and Walsh 1978, p. 245). Julian goes on to write that while we do not always live in peace and love, we must seek God's grace and Mercy, and so "it is fitting for us to live always in sweet prayer and in loving longing with our Lord Jesus" (eds. Colledge and Walsh 1978, p. 246). To live God's love requires cultivating a disposition of humility and a new subjective orientation. Julian's revelations on the nature of sin disarticulates her body-and women's bodies-from Church doctrine. It removes the negative mark of sin used to subjugate women within a politico-religious system of power. Rearticulated by humility and divine love, Julian occupies a new subjective position, asserting a new identity. 
Julian's theological insights are inseparable from the bodily experience of her revelations. The person of Julian, then, cannot be separated from her theology. This results in a strong authorial presence in Julian's writing. As both Felicity Riddy (1998) and Christopher Cannon (2003) contend, writing her revelations required self-description and the invention of an "I." One that, as Cannon writes, "links that subject to [the] text" (p. 119). As Judith Butler (1993) observes, the construction of an "I" is always constitutive (p. 7). Subjectformation relies on relations to power that precede the subject. That is, becoming requires some "thing" to come into. Julian's subjectivity is formed within her bodily relationship with God and the divine knowledge that comes from that union. Julian's embodiment of humility and love places her in new relationships to the world and with others. That is, her new subject position provides new possibilities for agency and a productive force for reorienting relationships.

Julian enacts this subjectivity in the way that she writes herself in her texts and in the way in which she constructs and addresses her audience. Through her experience, Julian's body became coterminous with God's substance and the Trinity. Her body is an authoritative site for knowledge-making. Yet, instead of claiming authority, she uses her experience to serve as a hermeneutic for understanding divine truth. After receiving her first vision and explaining the first revelation, for example, she writes "I was greatly moved in love towards my fellow Christians, that they might see and know the same as I saw ... for all this vision was shown for all men" (eds. Colledge and Walsh 1978, p. 190). As Julian continues, she embodies humility by subsuming herself in God's authority. Doing so, she guides her readers away from her and towards contemplating God's love. She writes:

"Everything that I say about me I mean to apply to all my fellow Christians, for I am taught that this is what our Lord intends in this spiritual revelation. And therefore I pray you all for God's sake, and I counsel you for your own profit, that you disregard the wretch to whom it was shown, and that mightly, wisely and meekly you contemplate upon God who out of his courteous love and endless goodness was willing to show it generally, to the comfort of us all" (eds. Colledge and Walsh 1978, p. 191).

Julian's writing is invitational. She uses the narrative of her own bodily experience to guide readers, so that they too experience the visions and develop their own felt revelations of divinity.

By turning her audience toward God's love, Julian positions herself as a visionary medium. Throughout her texts, then, Julian works to divert her authorial self. "I am not good because of the revelations," she writes, "but only if I love God better; and inasmuch as you love God better" (eds. Colledge and Walsh 1978, p. 191). Julian's authorial presence serves as a conduit that continually points her readers to God's love. Many scholars, however, point to Julian's "self-effacement" as a rhetorical strategy (Davis 2008; McAvoy 2008b; Summit 2003; Glenn 1997). These scholars suggest that mystical writing was one of the few avenues available to women to discuss divine knowledge, as they were excluded from many sites of divine learning. Jennifer Summit (2003) observes that the performance of feminine weakness and humility was especially important for medieval women writers, as it "show[ed] that her writing issues not from her individual consciousness but from a heavenly source" (p. 95). She continues that it places their writing within "a culturally available language" that disclaims feminine intellectual agency (p. 96). Glenn (1997) similarly suggests that the "only intellectual world within woman's reach" was that of wisdom gained through piety (p. 92). This required women to perform their piety. The suggestion from both Summit and Glenn is that by occupying a position of female submissiveness, women create a rhetorical space for expressing divine knowledge. Julian's self-effacement, however, extends the limits of cultural authority granted to women performing their piety. By authoring a text, Julian claims an authority and agency that other women of her day did not possess. To claim authority necessitated self-effacement. Yet, Julian's culturally intelligible self-effacement creates new possibilities for expressing 
her new subject position and her embodiment of humility within God's love, while also reorienting power and agency in space.

Power constitutes social relations through its organization of hierarchies, construction of identities, and accepted practices of cultural values. Julian's subjectivity does not extend gendered hierarchies. Instead, it reorients the relationships that she shares with her audience. As Judith Butler (1993) observes, the contours of social interaction are predetermined by power and its norms (2). How one addresses another is determined by one's relations to others in power. Julian addresses her audience from a position in unity and in God's love. Just as Julian merges with God during her revelations, Julian blends her authorial identity with her readers. Her self-effacement serves to diminish her authority and establish communion with her "fellow Christians." She writes:

"For truly [visons were] not revealed to me because God love s me better than the humblest soul ... If I pay special attention to myself, I am nothing at all; but in general I am in the unity of love with all my fellow Christians. For it is in this unity of love that the life consists of all men who will be saved" (eds. Colledge and Walsh 1978, p. 134).

Julian's shift from "me" to "all Christians" bonds her with her audience. To be within God's love necessitates that the subject be "all in one love" with all of humanity. It requires that Julian create a reciprocal identification with her readers and meet them on the same plane, without pretense and with the same grace with which one meets God. Her relationship with others replicates the nature of the Trinity. When first revealed to her, she sees the Trinity as three heavens: "none is greater, none is less, none is higher, none is lower, but all are equal in their joy" (eds. Colledge and Walsh 1978, p. 216). Julian's authorial identity embodies the nature of the Trinity and rewrites her relationship with her readers.

Julian's embodiment of her new subjectivity redirects authority and creates possibilities to reorient flows of power within the space of her anchorhold. Power is deployed through material practices. Shome (2003), however, observes that space is not static. She writes: "space [is] a product of relations that are themselves active and constantly changing material practices through which it comes into being" (p. 41). Or, as Chávez (2010) writes: "space is always becoming and incomplete" (p. 5). Power, then, is imminent. It manifests in the moment through a subject and is perpetuated through repeated practices of subjects in time and place. To put it differently, material environments discipline bodies and, in a kind of feedback loop, material practices reiterate power. Practices of a subject, then, "place" bodies within flows of power. Within the anchorhold, however, Julian's body is both in-place and out-of-place. She is enveloped and inscribed within the reiterative power of Church authority. Yet, the bodily experience of her revelations positions her body as a site of divine knowledge. Positioned this way, her body becomes a rhetorical-body-in-space. Both Shome (2003) and Chávez (2010) recognize the potential for the dynamic relations of bodies in space to subvert dominant political-social orders. Julian's physical relationship to God partially dis-articulates her body from the gendered hierarchy of the Church and anchorhold, and rearticulates her body within a new subjectivity. Mountford (2001) likens the nexus of cultural-political and spatial power as a grid (p. 42). One in which our movements and relations in space are contained within. In occupying her new, dual body space, Julian reorients power in space and produces new agentive possibilities. Remarkably, by enacting an agency that emerges from a new authority, Julian is able to occupy her deeply gendered body in a space that seeks to erase both her gender and body.

By the time that Julian wrote her revelations, nearly a millennium of religious doctrine and orthodoxy canonized by Church fathers had been inscribed on the practice of Christian worship. Power manifests through the institutional organizations of the Church, as well as the ritualized practices within material structures of the churches and parishes. In this setting, space assumes heuristic power. It organizes bodies and behaviors, it distributes and reiterates authority, and informs social relations and hierarchies. Observed this way, the body-in-space is a locus for power's manifestation. Power is performed through adherence to and repetition of norms and practices. The affective dimensions of power compel us. 
Examining how Julian reorients hierarchies and relations among power and space, and her body provides a hermeneutic for recognizing how our own spatial environments provide possibilities for developing practices that revise relations and create new agencies. Such a project invites us to investigate how and through what relations our subjectivities are articulated. We can never completely disarticulate from power. As Julian shows us, however, we can move through powers. Julian occupies a position both in and out of dominant power. Locating new spaces of authority allows us to enact new agencies and reorient relations of power in space and time. Furthermore, over time, cultivating practices of a new subjectivity revises power and its relations. This creates heterogenous ways to read space and power and occupy and direct our own bodies.

Funding: This research received no external funding.

Conflicts of Interest: The author declares no conflict of interest.

\section{References}

Blamires, Alcuin. 2003. Beneath the Pulpit. In The Cambridge Companion to Medieval Women's Writing. Edited by Carolyn Dinshaw and David Wallace. Cambridge: Cambridge University Press, pp. 141-58.

Butler, Judith. 1993. Bodies that Matter: On the Discursive Limits of 'Sex'. New York: Routledge.

Cannon, Christopher. 2003. Enclosure. In The Cambridge Companion to Medieval Women's Writing. Edited by Carolyn Dinshaw and David Wallace. Cambridge: Cambridge University Press, pp. 109-23.

Cedillo, Christina. 2015. Habitual Gender: Rhetorical Androgyny in Franciscan Texts. Journal of Feminist Studies in Religion 31: 65-81. [CrossRef]

Chandler, Erin T. 2012. The Present Time of Things Past: Julian of Norwich's Appropriation of St. Augustine's Generative Theory of Memory. Rhetoric Review 31: 389-404. [CrossRef]

Chávez, Karma. 2010. Spatializing Gender Performativity: Ecstasy and Possibilities for Livable Life in the Tragic Case of Victoria Arellano. Women's Studies in Communication 33: 1-15.

Colledge, Edmund, and James Walsh. 1978. Julian of Norwich Showings. New York: Paulist Press.

Davis, Carmel Bendon. 2008. Mysticism and Space: Space and Spatiality in the Works of Richard Rolle, The Cloud of Unknowing Author, and Julian of Norwich. Washington, DC: The Catholic University Press of America.

Evans, Ruth. 2003. Virginities. In The Cambridge Companion to Medieval Women's Writing. Edited by Carolyn Dinshaw and David Wallace. Cambridge: Cambridge University Press, pp. 21-39.

Glenn, Cheryll. 1997. Rhetoric Retold: Regendering the Tradition from Antiquity Through the Renaissance. Carbondale: Southern Illinois University Press.

McAvoy, Liz Herbert. 2008a. Gender Rhetoric and Space in the Speculum Inclusorum, Letter to a Bury Recluse and the Strange Case of Christina Carpenter. In Rhetoric of the Anchorhold: Space, Place and Body within the Discourses of Enclosure. Edited by Liz Herbert McAvoy. Cardiff: University of Wales Press, pp. 111-26.

McAvoy, Liz Herbert. 2008b. Introduction: 'God Forbede ... that I am a techere': Who, or what, was Julian? In Companion to Julian of Norwich. Edited by Liz Herbert McAvoy. Cambridge: D.S. Brewer, pp. 1-16.

Mountford, Roxanne. 2001. On Gender and Rhetorical Space. Rhetoric Society Quarterly 31: 41-71. [CrossRef]

Phillips, Kim A. 2008. Femininities and the Gentry in Late Medieval East Anglia: Ways of Being. In A Companion to Julian of Norwich. Edited by Liz Herbert McAvoy. Cambridge: D.S. Brewer, pp. 19-31.

Riddy, Felicity. 1998. Julian of Norwich and Self-Contextualization. In Editing Women. Edited by Ann M. Hutchinson. Toronto: University of Toronto Press, pp. 101-24.

Shome, Raka. 2003. Space Matters: The Power and Practice of Space. Communication Theory 13: 39-56. [CrossRef]

Summit, Jennifer. 2003. Women and Authorship. In The Cambridge Companion to Medieval Women's Writing. Edited by Carolyn Dinshaw and David Wallace. Cambridge: Cambridge University Press, pp. 91-108.

Watson, Nicholas. 1996. 'Yf Wommen be Double Naturelly': Remaking 'Woman' in Julian of Norwich's Revelation of Love. Exemplaria 8: 1-34. [CrossRef]

Watson, Nicholas. 2003. Julian of Norwich. In The Cambridge Companion to Medieval Women's Writing. Edited by Carolyn Dinshaw and David Wallace. Cambridge: Cambridge University Press, pp. 210-21.

Wright, Robert E. 1987. The 'Boke Performyd': Affective Technique and Reader Response in the 'Showings' of Julian of Norwich. Christianity and Literature 36: 13-32. [CrossRef] 